\title{
The Correlation Between Self Assessment and Speaking Ability of the Eighth Grade Students at Junior High School 16 Pekanbaru
}

\author{
Nurdiana \\ Universitas Islam Negeri Sultan Syarif Kasim Riau, Indonesia \\ nurdianaalda@gmail.com \\ Rina Dwi Khalistha \\ Universitas Islam Negeri Sultan Syarif Kasim Riau, Indonesia \\ rinadwikhalista@gmail.com
}

\begin{abstract}
This research is a correlational research, which aims at finding out the correlation between self assessment and speaking ability. There were two variables used in this research, was variable $X$ (Self Assessment) and variable Y (Speaking Ability). The subject of this research was the eighth grade students at Junior High School 16 Pekanbaru whereas the object of this research was the correlation between self assessment and speaking ability. The population of this research was 197 students. To choose the sample, the researcher used simple random sampling technique and got 40 students as the sample. In collecting the data, the researcher used questionnaire for self assessment and oral test for speaking ability. From the data analysis which had been done by using SPSS 20.0 version, it could be seen that there was a significant correlation between self assessment and speaking ability. It could be shown that the probability of score sig.t is 0.000 , smaller than the significant alpha of 0.05 (sig.t $<0.05$ ). It means that $\mathrm{HO}$ is rejected and $\mathrm{Ha}$ is accepted. In other words, there is a significant correlation between self assessment and speaking ability.
\end{abstract}

Key Words: Correlation, Self Assessment, Speaking Ability.

\section{INTRODUCTION}

Speaking is the process of building and sharing meaning through the use of verbal and nonverbal symbols in a variety contexts (Chaney, 1998, p.13). Speaking is essential to every aspect of life. It is very important to be learned by the students. Learning to speak fluently and accurately is one of the greatest challenges for all learners. Because, to be able to speak fluently, a speaker has to speak and think at the same time. When speaking, a speaker has to monitor their output and correct any mistakes, as well as planning for what they are going to say next. To be able to speak fluently in a foreign 
language requires a lot of practice. Speaking practice starts with practising and drilling set phrases and repeating models. Fluent speakers will also have to learn a range of other things such as what is appropriate to say in certain situations, how to manage conversations, and how to interrupt and offer their own contributions. It is a difficult and long process to master all these subskills.

Speaking is also defined as the productive aural/oral skill which consists of producing systematic verbal utterances to convey meaning (Nunan, 2003, p.48). Furthermore, Richards \& Renandya (2002, p.204) described that effective speaking requires the ability to use the language appropriately in social interactions that involves not only verbal communication but also paralinguistic elements of speech such as pitch, stress, and intonation. Moreover, nonlinguistic elements such as gestures, body language, and expressions are needed in conveying messages directly without any accompanying speech. The main goal from speaking is a means of communication.

In Junior High School 16 Pekanbaru, teaching learning process uses school based curriculum. According to standard competence in the syllabus, the students are required to be able to express the meaning of functional text and simple short monologue descriptive and recount to interact with their environment. Based on the preliminary observation, the English teacher used communicative approach to gain the students' participation to increase the students' speaking performance. The steps done by the teacher are:
The teacher came to the class with full of spirit and gave motivation to encourage the students.

2. The teacher set the clear and achievable goal of a task to do by the students.

3. The teacher gave an example of a good presentation in front of the class. She also used media as one of tools to support learning process.

4. The teacher gave support and appreciation to all of the students.

5. The teacher did not give direct correction while the students did mistakes in their performance.

6. The teacher gave clear and understandable reflection after all of the performances.

In fact, the reality has shown that some of the students were not able to achieve the standard competence although those efforts had been done in terms of teaching speaking itself. It was still far from what the curriculum expected. Some of students still had difficulties in learning speaking. It could be identified where most of the students could not reach the passing grade. The students' passing grade was 76.

Those problems above can be caused by several factors such as their self assessment. According to Alibakhshi \& Abbaszadeh (2012), self assessment can influence students' speaking performance. It means that the process to enhance students' speaking ability is supported by self assessment. By doing self assessment, the students can be extremely effective at monitoring and judging their own language production, they frequently have a clear idea of how well they are doing or have done (Harmer, 2001, p.102). It also makes students more 
active in judging their own progress and encourages them to see the value of what they have learned (Nedzinskaite in Tavakoli, 2009, p.6).

Regarding to the previous ideas, when students are involved in their own assessment, there is a good chance that their understanding of the feedback which their teacher gives to them. In fact, some of the students were not able to maximalize self assessment in their speaking class. In short, the phenomena can be seen as follows:

1. Some of the students were not able to apply an independent individual learning in speaking class.

2. Some of the students were not able to monitor their own progress about how well their performance was.

3. Some of the students were not able to judge their own activities during learning process to improve their better speaking performance.

4. Some of the students were not able to identify their learning goals in the end of speaking activities.

Based on the phenomena above, it is clear that some of the students still have problems in their self assessment and speaking. The aim of this research is to investigate whether there is a significant correlation between students' self assessment and their speaking ability.

\section{Formulation of the Problem}

Based on the problems above, the researcher formulates the problems ofthe Eighth Grade Students at Junior High School 16 Pekanbaru in the following questions :

a. How is self assessment of the Eighth Grade Students at Junior High School 16 Pekanbaru?

b. How is speaking ability of the Eighth Grade Students at Junior High School 16 Pekanbaru? c. Is there any significant correlation between self assessment and speaking ability of the Eighth Grade Students at Junior High School 16 Pekanbaru?

\section{Objective of the Research}

Based on the formulation above, the objectives of the research are :

a. To find out how self asssessment of the Eighth Grade Students at Junior High School 16 Pekanbaru

b. To find out how speaking ability of the Eighth Grade Students at Junior High School 16 Pekanbaru

c. To find out the significant correlation between self assessment and speaking ability of the Eighth Grade Students at Junior High School 16 Pekanbaru.

\section{METHOD}

The design of this research is a correlational research. It deals with exploring relations that exist between variables. Correlational research helps to clarify relations among variables (Schunk, 2008, p.4). There were two variables in this research: independent variable and dependent variable.

The independent variable is a stimulus variable or input, it is that factor which is measured, manipulated, or selected by the experimenter to determine its relationship to an observed phenomenon. Meanwhile, the dependent variable is response variable or output, it is that factor which is observed and measured to determine the effect of the independent variables (Riadi, 2016, p.52). In this research, self assessment is the independent variable and symbolized by $X$, and speaking ability is the dependent variable and symbolized by Y.

The research was conducted on March in academic year 2017/2018. 
SMPN 16 Pekanbaru is located at Jln. Cempaka No. 16 Pekanbaru.

The subject of this research was the Eighth Grade Students at Junior High School 16 Pekanbaru. And the object of this research was self assessment and speaking ability.

The population of this research was the Eighth Grade Students at Junior High School 16 Pekanbaru. There were five classes which consisted of 197 students. It can be seen in the following table:

\section{Population}

$\begin{array}{ccc}\text { No } & \text { Class } & \text { Students } \\ 1 & \text { VIII.1 } & 37 \\ 2 & \text { VIII.2 } & 40 \\ 3 & \text { VIII.3 } & 36 \\ 4 & \text { VIII.4 } & 42 \\ 5 & \text { VIII.5 } & 42 \\ \text { Total } & & 197\end{array}$

Because the population was large, so the researcher used simple random sampling. Gay (2012: 131) stated that simple random sampling is the process of selecting a sample in such a way that all individuals in the defined population have an equal and independent chance of selecting for the sample. Arikunto (2006, p.134) stated that if the population is less than 100 , it is better to take all of them as the sample but if the total population is more than 100 students, the sample can be taken between $10-15 \%$ or $20-25 \%$ or more. The researcher took $20 \%$ of the population as the sample by putting all the little rolled-up papers that contained all of the students' names into a box and picking them up one by one until getting 7-9 students' names for each class. The percentage of sample can be seen in the table below :

\section{Sample}

$\begin{array}{llll}\text { No } & \text { Class } & \text { Students } & \begin{array}{l}20 \% \\ \text { from } \\ \text { total } \\ \text { student }\end{array} \\ & & & 7 \\ 1 & \text { VIII.1 } & 37 & 8 \\ 2 & \text { VIII.2 } & 40 & 7 \\ 3 & \text { VIII.3 } & 36 & 9 \\ 4 & \text { VIII.4 } & 42 & 9 \\ 5 & \text { VIII.5 } & 42 & 9 \\ \text { Total } & & 197 & \\ \text { Population } & & \\ \text { Total Sample } & & 40\end{array}$

In order to collect the data in the research, the researchers used questionnaire and test.

The questionnaire was used to know students' self assessment which was adopted from Brown (2003). The questionnaire dealth with learners' opinion in responding self assessment in language learning by using likert scale which consists of 25 positive statements. It has been translated into bahasa indonesian by the researcher. And Test was used to know students' speaking ability, the researcher used retelling story. There were some topics given such as description about pet, house, family, school, room. 


\section{RESEARCH FINDINGS}

1. Self Assessment of the Eighth Grade Students at Junior High School 16 Pekanbaru

\begin{tabular}{|c|c|c|c|c|c|}
\hline \multicolumn{6}{|c|}{ Descriptive Statistics of Self Assessment } \\
\hline $\mathrm{N}$ & \multicolumn{2}{|c|}{ Minimum } & Maximum & Mean & Std. Deviation \\
\hline Self & 40 & 54 & 78 & 66,35 & 5,895 \\
\hline Asse & & & & & \\
\hline Vali & vise) & & 40 & & \\
\hline
\end{tabular}

The table explains that the mean of self assessment was 66.35. The standar deviation was 5.895, minimum score was 54 and maximum score was 78. Based on the category provided in chapter III, the data of self assessment is categorized as follows:

\section{Analysis Criterion of Self Assessment}

$\begin{array}{lll}\text { No } & \text { Scores } & \text { Categories } \\ 1 & 81 \%-100 \% & \text { Very high } \\ 2 & 61 \%-80 \% & \text { High } \\ 3 & 41 \%-60 \% & \text { High enough } \\ 4 & 21 \%-40 \% & \text { Low } \\ 5 & 0 \%-20 \% & \text { Very low }\end{array}$

Based on the categories above, it can be concluded that the self assessment of the eighth grade students at junior high school 16 pekanbaru was high because the percentage obtained was $66.35 \%$. Thus, the first research problem which was formulated and had been current issue in the school recently was answered.

2. Speaking Ability of the Eighth Grade Students at Junior High School 16 Pekanbaru

\begin{tabular}{|c|c|c|c|c|c|c|}
\hline \multirow[b]{2}{*}{$\mathrm{N}$} & \multicolumn{5}{|c|}{ The Descriptive Statistic of Speaking Ability } & \multirow[b]{2}{*}{ Variance } \\
\hline & & & Maximum & Mean & Std. & \\
\hline $\begin{array}{l}\text { speaking } \\
\text { ability }\end{array}$ & 40 & 33 & 73 & 53,97 & $\begin{array}{r}\text { Deviation } \\
7,195\end{array}$ & 51,769 \\
\hline Valid N & wise & & & 40 & & \\
\hline
\end{tabular}

The table explains that the mean of speaking ability was 53.97. The standad deviation was 7.195 , minimum score was 33 and maximum score was 73. Based on the category provided in chapter III, the data of speaking ability is categorized as follows:
Analysis Criterion of Speaking Ability

$\begin{array}{lll}\text { No } & \text { Scores } & \text { Category } \\ 1 & 80-100 & \text { Very Good } \\ 2 & 66-79 & \text { Good } \\ 3 & 56-65 & \text { Enough } \\ 4 & 40-55 & \text { Less } \\ 5 & 30-39 & \text { Fail }\end{array}$


Based on the categories above, it can be concluded that speaking ability of the eighth grade students at junior high school 16 pekanbaru was less.
Thus, the second research problem which was formulated and had been current issue in the school recently was answered.

\section{Correlation between Self Assessment and Speaking Ability of the Eighth Grade Students at Junior High School 16 Pekanbaru}

\section{Correlations Result}

$\begin{array}{lcccc}\begin{array}{l}\text { Self assessment } \\ \text { self assessment }\end{array} & \begin{array}{l}\text { Pearson } \\ \text { Correlation }\end{array} & 1 & , 547 * * \\ \begin{array}{l}\text { Sig. (2-tailed) } \\ \text { N }\end{array} & 40 & , 000 & 40 & \\ \text { speaking ability } & \begin{array}{c}\text { Pearson } \\ \text { Correlation }\end{array} & , 547 * * & & 1 \\ \text { Sig. (2-tailed) } & 40 & , 000 & & \\ \text { N } & 40 & 40 \\ * * \text { Correlation is significant at the } 0.01 \text { level (2-tailed). }\end{array}$

Pearson correlation was conducted in this research in order to determine if there is significant correlation between self assessment and speaking ability of the eighth grade students at junior high school 16 Pekanbaru. Based on Pearson analysis for students' self assessment and their speaking ability in table IV.35 above, It can be seen from the sig.(2-tailed) value. In the table above, sig-t was 0.000 . It was smaller than 0.05 (sig-t < 0.05 ). The result shows that the scores did correlate between self assessment and speaking ability of the eighth grade students at junior high school 16 Pekanbaru.

In addition, the table above also shows that the coefficient correlation in this research was 0.547. Furthermore, there was also the symbol **. It is clear that there is a positive correlation between self assessment and speaking ability. Meanwhile, in order to know the level or strength of correlation between two variables, Riduwan (2011, p.228) provides the following categories:
The Interpretation of Correlation Coefficient

$\begin{array}{rll}\text { No } & \begin{array}{l}\text { Coefficient } \\ \text { Interval }\end{array} & \begin{array}{l}\text { Level of } \\ \text { Correlation }\end{array} \\ 1 & 0.00-0.20 & \text { Very Low } \\ 2 & 0.20-0.40 & \text { Low } \\ 3 & 0.40-0.70 & \text { Medium } \\ 4 & 0.70-0.90 & \text { High } \\ 5 & 0.90-1.00 & \text { Very High }\end{array}$

The correlation coefficient obtained was 0.547 which means the level of correlation between self assessment and speaking ability of the eighth grade students at junior high school 16 Pekanbaru was medium. Thus, the third research problem which was formulated and had been current issue in the school recently was answered.

Furthermore, to find out how significant the correlation between self assessment and speaking ability at the eighth grade students of Junior High School 16 Pekanbaru is, the $\mathrm{R}$ determination should be found. According to Riduwan (2011, p.228), 
determinant coefficient is the value that is used to know the contribution given by variable $\mathrm{X}$ to variable $\mathrm{Y}$. The following is the process of getting the $R$ determinant :

$$
\begin{aligned}
\mathrm{R} & =(\mathrm{r}) 2 \times 100 \% \\
\mathrm{R} & =(0,547) 2 \times 100 \% \\
& =29.92 \%
\end{aligned}
$$

So, the $\mathrm{R}$ determinant obatained was $29.92 \%$. It means that $29.92 \%$ speaking ability at the eighth grade students of Junior High School 16 Pekanbaru was influenced by self assessment. Then, the other $70.08 \%$ was influenced by other factors.

\section{CONCLUSION}

Based on the previous explanation, it can be concluded that:

1. Self assessment of the Eighth Grade Students at Junior High School 16 Pekanbaru was found in "high" category.

2. Speaking ability of the Eighth Grade Students at Junior High School 16 Pekanbaru was found in "less" category.

3. There is a correlation between self assessment and speaking ability of the eighth grade students of Junior High School 16 Pekanbaru in "medium" category.

\section{REFERENCES}

Alibakhshi, G. \& Abbasszadeh, S. (2012). The impact of selfassessment on Iranian EFL learners' writing and speaking. Yasuoj University: Yasuoj Iran.

Andrade, H. \& Du, Y. (2007). Student responses to criteria referenced self assessment: Assessment and evaluation in higher education. 32(2), 159- 181.
Arikunto, Suharsimi. (2006). Prosedur penelitian suatu pendekatan praktik. Jakarta: Rineka Cipta.

BSNP. (2006). Standar kompetensi dan kompetensi dasar SMP/MTs. Jakarta.

Brown, H. D. (2003). Language assessment principles and classroom practice. California: Longman.

Chaney, A. L. \& T. L. Burk. (1998). Teaching oral communication in grades $K$ - 8. Boston: Allyn \& Bacon.

Creswell, J. W. (2012). Educational research: planning, conducting, and evaluating quantitative and qualitative research. fourth edition. Boston: Pearson Education, inc.

Dornyei, Zoltan. (2003). Questionnaires in second language research: construction, administration, and processing. London: Lawrence Erlbaum Associates, Inc.

Gall, M. D. et al,. (1996). An introduction educational research sixth edition. Longman Publishers USA.

Graham, Alan. (1994). Statistics. US: NTC Publishing Group.

Gunning, T. G. (2012). Creating literacy instruction for all students in grades 4-8 third edition. Pearson Education, Inc.

Harmer, J. (2001). The practice of English language teaching third edition. London: Longman.

Hughes, A. (2003). Testing for language teachers. Cambridge University Press.

McMillan, James H. \& Hearn, Jessica. (2008). Student self-assessment: 
the key to stronger student motivation and higher achievement. Educational Horizons.

McNamara, T. (2000). Language testing. Oxford: Oxford University Press.

Nugraheni, Aninditya. (2012) Pengajaran bahasa berbasis karakter. Yogyakarta: Mentari Pustaka.

Nunan, David. (2003). Practical English language teaching. Mc Graw-Hill companies Inc.

Pratama, Melgis. D. (2015). TEYL. Pekanbaru: Adeka Grafika.

Riadi, Edin. (2016). Statistika penelitian. Yogyakarta: Penerbit Andi.

Richard, Jack C. (2002). Methodology in language teaching. USA: Cambrige University Press. (2008). Teaching listening and speaking. Cambridge: University Press.

Riduwan. (2011). Dasar-dasar statistik. Bandung: Alfabeta.

Schunk, D. H. (2008). Learning theories: An educational perspective fifth edition. Pearson: Merrill Prentice Hall.

Shahrakipour, Hassan. (2014). On the impact of self-assessment on EFL learners receptive skills performance. AJTLHE Vol 6(1) 1-13.

Sincich, Mcclave. (2009). Statistics. USA: Pearson Education, Inc.

Spiegel, M. R. (2009). Statistik. PT Gelora Aksara Pratama.
Sudijono, Anas. (2008). Pengantar evaluasi pendidikan. Jakarta: Raja Grafindo Persada.

Syafii S, M. (2015). From paragraphs to a research report: A writing of English for academic purposes. Pekanbaru: Suska Press.

Tavakoli, Mansoor. \& Goorchaei, Behrooz. (2009). On the relationship between risk taking and self assessment of speaking ability: a case o freshman EFL learners. 6(1), 1-27.

Thornbury, S. (2005). How to teach speaking. New York: Pearson Education Inc.

Wahyudi, Dedi. (2013). Guideliness of teaching speaking: Theory and practice. Kreasi Edukasi.

Wilujeng, Trisno. (2014). Metode self assesssment sebagai metode alternative dalam melakukan evaluasi belajar mahasiswa. JIBS 